\title{
What Are the Facts in Online Nursing Education During the Covid-19 Pandemic?
}

\author{
$1^{\text {st }}$ Devi Mediarti \\ Nursing Department \\ Poltekkes Kemenkes Palembang \\ Palembang, Indonesia \\ devimediarti@poltekkespalembang.ac.id \\ $3^{\text {rd }}$ Yunike \\ Nursing Department \\ Poltekkes Kemenkes Palembang \\ Palembang, Indonesia \\ yunike @poltekkespalembang.ac.id
}

\author{
$2^{\text {nd }}$ Ira Kusumawaty \\ Nursing Department \\ Poltekkes Kemenkes Palembang \\ Palembang, Indonesia \\ irakusumawaty@poltekkespalembang.ac.id \\ $4^{\text {th }}$ Rika Oktarina \\ Nursing Department \\ Poltekkes Kemenkes Palembang \\ Palembang, Indonesia \\ rikaoktarina@poltekkespalembang.ac.id
}

Corresponding author: irakusumawaty@ poltekkespalembang.ac.id

\begin{abstract}
During the Covid-19 pandemic, there are a series of direct skills skills for nursing students. Changes in the learning force can have an impact on the faces of students and their learning achievements. However, the question of student olahihan problem in the way of isasi kecenyanyanya is still minimal. This research became the learning of psychomotor skills through online methods of student perspective. This qualitative research exists in a phenomenological way, which is capable of five student participants who are circling semi-class questions. The images are shaped, then analyzed using Colaizzi's way of forming seven themes. Formulation of themes: beautiful at the beginning of online learning, character role of reason, tasks that are city, real practical expectations, loss in learning learning, self-learning. The results of subdistrict research, the root in learning psychomotor skills online way is a large loan for education providers for reconstruction systems centered on students and independent students. Guidance guidance on misunderstanding guidance for students in a change of way up to the future.
\end{abstract}

Keywords: facts, online nursing education.

\section{INTRODUCTION}

The Covid-19 pandemic was declared by the World Health Organization (WHO) in the period March 1, 2020, beginning with the risk of wuhan city residents in China spread to cases in almost every country [1], globally the confirmed cases were 5,406,282 with 34 3,526 deaths in the Health Ministry data on Covid-19 incidents in Indonesia in Indonesia are located on March 15, 2020 as many as 21 cases continue to be 700 cases as of May 31, 2020 there is a very drastic peak [2].

The character of covid-19 disease is very quickly the government for social ditanching policy is lowered, pshysical distancing and stay at home to lock down certain areas. Singkun against the change of urgency for whichever is better. The government set out the rules in placeswhere associations might include schools and universities in subdistricts in public healthsubdistrictsin the future. Lockdown is carried out where many countries with protocols in india [3], while the Indonesian government policy only imposes lockdown in the region in the region must be for the process of smuggling policy more and more, the government is increasingly conducting large-scale protocols (PSBB), PSBB again said health quarantine in Indonesia that caps during the distance activities in the territory of suspected disease or disease. Diliburkan all offline activities by means of teaching and learning activities with an online system protocol will be possible for the pandemic so efforts to prevent the transmission of Covid-19. Learning boldly on top of what is juxtaposed in E-learning that can be done internet learning, distributed learning, virtual 
learning, computer-assisted (CAL) [3]. This convenient talk a lot, very quick changes and all the systems around this are done probably by both students, teachers, students and parents. Among the emerging student readiness, mastery of technology, other constraints where the system has been. While the positive effect of online learning is the open borders of another country, so that lecturers and students of creative students, making up to build a wide network with people both in their plots and between fields in different parts of the world [4].

The practice of practicing will be up to the birth of psychomotor which will be the skill which is which is held by nursing students. Which is what there is nothing students practice practice in the Laboratory to the future. The results of the study [5] figure with a method of the best possible for students berdingkkah for which students are really good. However, the method of using online by providing simulation of student practice becomes the main choice to achieve nursing student practice, this is in line with its standards, e-learning methods and jur simulation in nursing school nursing programs. American Association of Colleges of Nursing and the National Council of State Boards of Nursing also stated that simulation and location of online learning learning in nursing education. One of the usual strategies so alternative stu- dents match this recommendation again simulation

Online learning results learn skills directly for nursing students and this is until today's students they have to practice it in the real world. Changes in the way learning learns can have an impact on the face of the student's sorry face and achievements of learning achievement. The education system in Indonesia is not ready to use learning technology with a bold system or online Even with this system, there are students who expose themselves to their mistakes, stress and do not learn to learn properly and correctly [6]. Investigations into the present day of nursing students in how to learn online are still minimal, para experts are onstandby for admissionpatients with severe illnesses during the COVID-19 outbreak at mental health institution services for students andstudents[ 8]. The above phenomenon has been responded to by the government and educational institutions

The purpose of this study was to look at the phenomenon where nursing students are in psychomotor skills through online methods. Nursing students have a high sks load to transport psychomotor births both through laboratories and field work practices in the practice field. Nursing students have a target of meeting well with the players for nursing doctors related to moderate care according to him is in communication and communication directly from the players [7] Online learning students to learn to learn in laboratories and practice land using equipment, practicing and communicating directly, this is very minimal root achievements where they can. Only with the system in the middle will be remembered online of the phenomenon both koghnitif, affective and pskimotor and very good on pskilogi made by students [8].

This research is the creation of students where possible will be clear to the results of the research. Beautiful psychomotor learning in particular that becomes a complement to nursing students, and will also be around where to do anything online especially in nursing students and kuingkut students. How to transport a bold what is the right way to include nursing and affective for him both from the side of students and lecturers

\section{METHOD}

This qualitative research exists where by way of copological phenomenology description. Three Steps in descriptive phenology, intuition, journaling, and the image in which [9]. The population in this study was a third semester (Three) nursing student in Palembang. Sampling using Purposive sampling which is a selection by researchers on the subject / element that exists for the study in a source of information. This research is integrated at the 5th level where there is more or which theme of the questions is which, which students use learning technology in lectures in online lectures? Difficult and what are the easy things where students learn online?, How big is the high task and the level of stress that students in online lectures? What support systems are students in the covid-19 period?

\section{RESULTS}

Informants in this study are III (Three) nursing students Poltekkes Kemenkes Palembang. Sectionpan consists of 3 men and 2 women who in semester III (three) where in the semester had previously been laboratory practice. Typical information is presented for the research pulp of type results, GPA, social status, residence and family role. 
Table 1. Time-informing informant

\begin{tabular}{|c|c|c|c|c|}
\hline No & Characteristics & & Amount & Making-share (\%) \\
\hline \multirow[t]{3}{*}{1.} & Types of Berku & & & \multirow{3}{*}{$60 \% 40 \%$} \\
\hline & - Male & & 3 & \\
\hline & Women & & 2 & \\
\hline \multirow[t]{3}{*}{2.} & Gpa & & & \multirow{3}{*}{$80 \% 20 \%$} \\
\hline & $>3$ & & 4 & \\
\hline & $-\quad \leq 3$ & & 1 & \\
\hline \multirow[t]{3}{*}{3.} & Social Status & & & \multirow[b]{3}{*}{$50 \% 50 \%$} \\
\hline & High & & 2 & \\
\hline & Low & & 2 & \\
\hline \multirow[t]{3}{*}{4.} & Neighborhood & & & \multirow{3}{*}{$80 \% 20 \%$} \\
\hline & - City & & 4 & \\
\hline & State & & 1 & \\
\hline \multirow[t]{4}{*}{5.} & \multicolumn{2}{|l|}{ Parents } & & \\
\hline & There is & & 5 & $100 \%$ \\
\hline & - $\quad$ There's & amom/dad & 0 & $0 \%$ \\
\hline & None & & 0 & $0 \%$ \\
\hline
\end{tabular}

Themes that can be where the picture after the existence of coding data and qualitative analysis in this research are: living at the beginning of online learning: expression of the following informants who are among the circles:

.... sometimes uncomfortable learning online, often the disruption of what signals are taught lecturers sometimes break up. I'm not going to say that.

..... suddenly all the lecture material was online, difficult to discuss ... time is also limited... want a lot of time abis nanya.....

I'm not going to say that.

... especially the practice tuh want to practice nyuntik at home, can not pake enter .. we also just learn through vidio and zoom nyuntik practice reply I'm not comfortable with this sudden online (P5).

Very drastic changes and word changes [10]. Online learning until 2006, but has not learned to be the main [5]. The Covid-19 pandemic is coming very quickly and the drastic and double change of students is so fast by way of methods and this is up to a lot of them. The results of the study [6]. Students in online classrooms feel that they are working hard to shock the rapid system in the COVID-19 pandemic so that they are not ready around or in others such as being stuck in lockdown areas through PSBB regulations, so they have to stay at home where internet access is not optimal

Be careful what your husband says: The informant's expression has a theme:

.... I'm afraid kalo kalo kalo be a woman's head, I can not while learning online, we just seem to not be able to, for tools that are not at home (P1).

.... I'm not pede later if directly meet patients, just asked by neighbors about Covid-19 I doubt wrong when I feel the knowledge that I can at the right source, I rarely sub-district with lecturers since learning online I'm not going to say that.

.... I'm a pandemic fisherman soon belalu, when kalo kalo until the end of education we learn to learn online, what about which skills and good for where less (P5). health learn procedural medical skills, existing transmissions on and off, under conditions in supervision and face-to-face feedback [5]. Students of sub-district students must be in nursing care today by doing stages of the nursing process starting from the assessment to the counter-stage students meet with the team or so that the team and results can be hoisted by the husband. Which nursing practices learn to learn are vague when filled with online methods. This matches the results of the study [11]. Students are more than more than more than just theories that you think the way they are, they really can be done.

All tasks, expressions of informants whose theme is:

All lecturers assign assignments at each end to end. and so heavy it's all so put immediately, and should be uploaded to classroom or google drive, sometimes the signal can not, especially for me and friends who live in the area that makes not signal we have to leave the village first" ( P1)

...... Assignments basically make us stuck to think, with the task so many know, since the tasks of online learning is very much and the task is not much berbuntu.. I'm not going to say that.

.... kalo before the pandemic many assignments in groups and work together with friends, and can come for guidance, but since online assignments many individuals, although there is a discussion room but not as effective if face to face I'm not

going to say that.

The online learning force of students for assignment assignments feedback assignments from which learning. [12] states successful online courses for law are frequent assignments, short assignments, and discussion forums centered around which questions trigger a course drawing and a student image of a student. The assignment is an indication of whether the material where lecturers are good, in learning lessons online lecturers and students are very limited. Assignments where students are ringed for students, both from where and also directly, students can not link, students can not bero from anywhere where they do directly with lecturers. [5] state alerts and easy great learning to learn languages online number real-time results between students and drivers, and in a way become a vehicle for students to feedback. Expectations of real practical education, Expression Informants whose theme is: 


\begin{abstract}
.. kalo I again like to study in the laboratory, see firsthand the demonstration where lecturers then I re-demonize it Back and get in from the lecturer, besides it can be a lot about which in practice ... I'm not going to say that.
\end{abstract}

...... how sophisticated the video about the way if not the sub- district discussion will not be maximal, let alone not practiced directly. Can't practice we can't have the skills that teach the mind... I'm not going to say that.

" kalo study in the laboratory we see can directly demonstrate the details of nursing actions and we can do redemonstrasi with guidance by lecturers or laboratories and this interesting learning learning (P4) ...... learn online it seems to me riweh, not practical ... internet reply smoothly delicious .. whose signal is jammed hard.. reply lecturers are practicing in zoom, suddenly lost signal so can not ngikutin .. and we can't practice the word at home.. I'm not going to say that.

Learning online is going one to one that brings a lot of work...[13] nursing learning began to be directed to online learning since 2006 [14]. Students live with googclass, E-Vilep and Zoom and other outbreaks before covid-19, but the percentage of online learning in bold learning is still again and focused on learning theories only ..... [15]. Nursing practice is carried out permanently in the laboratory using pantom or people on coban in the laboratory. This is in line with the results of a study (Glen,2014) which found that Teachers in online situations cannot be exclusively concerned about themselves and their students, because they are also interconnected with each other and other individuals.

Read the practice is very exercise to improve which practical, psychomotor skills which from seeing and anything in the laboratory so that can be directly said. The theme is indicated in this study where students expect practical and real practical practice methods, and redemontration methods by direct students with guidance will be the most important thing. This is in line with [16] statement, 1997 which stated There is social in the online language correlated with the value of learning far from online [16]. And the statement [5] that online learning is the way other students are in small groups or in conversational sessions in sync with other students. Teachers also apply to real life because, as stated by one teacher," said another nursing practice that orientates the field.

Loss in the sound of sound, Informant Expression whose theme is:
..... Learning online is like learning alone aja can not joke with friends, discussions on online again quiet from direct lectures, limited ideas to be revealed in online classes" (P2)

...... I prefer to face to face when studying, can discuss with friends and when meeting with lecturers and friends again the spirit is still learning to learn" (P4)

....... Kalo in our class can be many things, can science from lecturers and friends (P5)

The world's most diverse class for students, education in a classroom consisting of many people with varying knowledge and hats is a factor that many students in education [8]. Discussion and mutually expressing ideas and opinions in one talk group will add material that is sometimes not conveyed by lecturers. Online classes were removed among students, so the scientific gap was limited. This is stated by [5]. However, it's critical "that's what if anything in this virtual world, and we're dedicated to the profession of learning [where] human contact again nuts and bolts it. And the results of research [17] results of Telkom University students as much as, $90 \%$ strongly agree with face-toface lectures.

Independent Talk Market, Expression Informant theme of this theme:

again really can set the time of the task of brewing, kao not keteter, even though the task bansyak, so if I, kalo dah can be my task directly to completion or in the scheduled completion time (P1)

....... Kalo the task that we do is good, there is no right alone and it's really time ngerjain" (P3)

........ My name is not on the wall of the room u tuk every my college assignments, when where deatine so that I can task calmly not rush to make it.

Online learning effects of self-learning, students must be able to stray themselves to file assignments with a good time. Training onilne independent troops both good science in doing tasks and also can brew the time they have so that the task can be as a child. The course of the task which with achievements between and the time of arrival, very from wherever students curate themselves, this can be one that students hope to be independent. In accordance with the stated by [18].

The online learning force is a tool where students can practice not in the laboratory. What technology might be students in online learning but it's like the situation of the world and we're at them concepts that he anya [19]. One of the technology which can simulate the mathematics, student action students through online, still have to be marengi on a system that can score 
koghnitif, affective psycho andmotor students with learning which. In other studies how to online application of e-druf with ballots resulting from the package cal-culations e-drug, distance Cognitive Load Theory, especially online better decisions in the amount of student voice and self-efficacy, in which students are very good packages in the way than students who use. In other studies also the field of development of methods that may $t$ creation of online supplementation unit learning web-based on intrapartum care results are good results prove that there are alternatives that can be student learning activities. These results are also important for nursing students it could be a dent confi that web-based education units, tools added, efficient direct their educational activities.

The development of the force is up to 1000 ways to support students in a way that is a change of vision. The condition of the condition of the students of the village defense process that went through and the system besra body immunity, while the pandemic conditions that bersilah iniarus kan berbilitas individuals so as not to become victims of the Covid19 pandemic. The existence of a good mental disorder either where the student or the student is stressed, so nyorang street management faculty nothing on training and skinny short technology short of online use and exchange the existence of the weight of college aid and [10]. Poltekkes Palembang provides full support with learning trainings for lecturers so that the material can be online as possible, and support provides for students in the form of quota quota and application development system where the education of defense and assessment.

Hospital support is also needed by students of Palembang Poltekkes through the field of student cooperation with the education unit of 700 policdV. officers on stress management accompanied by mentoring through online hypnotism, positive affirmations, quadrilateral breath techniques and to him, $\mathbf{V}$. this is in line with research [20] research in which this is remembered phenomenon, participants are grateful for the positive expectations given by God wishes for an independent hypnosis trial. So five-finger hypnosis is good to please be a small victim of the group of people in monitoringCovid-19. Support that also greatly crystallises students as well as family support, the results of research [21] in a qualitative way towards families patient with mental disorders in the community, expressed the phenomenon of families who are confirmed, while training in viruses are farming horticulture, families have equality, patience, sincerity and a strong safe self.

Teman Sama Juga is also very much loved by students in learning, so that students in discussions in learning online will also be a form of support for students, this is in line with research with peers [22]. The main reason derived from the school environment is the influence of friends, the school environment will be a place of kitasi with their peers, so that the influence of friends. In the online method the class meeting is as big as a chat room and zooms small groups so that students stay connected with the same friends.

The family is also a system, consisting of members namely: father, mother, and child or all individuals who live together in one house. The existence of mutual interaction, interrelation and interdependence between family members is a characteristic of a family that makes a strong bond between fellow family members. This power unites to achieve a common goal. The family is an open system so that it can be influenced by the supra system namely: the environment or society and vice versa as a sub system of the environment or society, the family can influence the community (supra system) therefore how important the role and function of the family in shaping humans as members of society healthy bio-psycho-socialspiritual. So it is appropriate if the family have as a central point of nursing services.

\section{CONCLUSION}

The results of research in the root sub-district in learning psychomotor online way is a large loan for education providers for education services that are centered on students and enables students to improve which is best independent. Guidance on health guidance for students in how to learn from educational institutions and systems and also families as a companion for students to study at home online.

\section{ACKNOWLEDGMENT}

The author of both the institution of love and Pend rasa to the Community in poltekkes Ministry of Health Palembang has been providing research opportunities.

\section{REFERENCES}

[1] Organization WH. WHO Director-General's opening remarks at the media briefing on COVID-19. 2020.

[2] Univ JH. Coronavirus COVID-19 Global Cases by Johns Hopkins CSSE. 2020.

[3] Shenoy V, Mahendra S, Vijay N. COVID 19 Lockdown Technology Adaption, Teaching, Learning, Students Engagement and Faculty Experience. Mukt Shabd J 2020;9:698-702.

[4] Li W, Yang Y, Liu ZH, Zhao YJ, Zhang Q, Zhang L, et al. Progression of mental health services during the COVID-19 outbreak in China. Int J Biol Sci 2020;16:1732-8. 
https://doi.org/10.7150/ijbs.45120.

[5] Smith GG, Passmore D, Faught T. The challenges of online nursing education. Internet High Educ 2009;12:98-103. https://doi.org/10.1016/j.iheduc.2009.06.007.

[6] Kusnayat A, Sumarni N, Mansyur AS, Zaqiah QY, Bandung UT. Pengaruh Teknologi Pembelajaran Kuliah Online Di Era Covid-19 Dan Dampaknya Terhadap Mental Mahasiswa. EduTeach J Edukasi Dan Teknol Pembelajaran 2020;1:153-65.

[7] Authement RS, Dormire SL. Introduction to the Online Nursing Education Best Practices Guide. SAGE Open Nurs 2020;6. https://doi.org/10.1177/2377960820937290.

[8] McIntyre M, McDonald C, Racine L. A critical analysis of online nursing education: Balancing optimistic and cautionary perspectives. Can J Nurs Res 2013;45:36-53. https://doi.org/10.1177/084456211304500105.

[9] Drummond K, Murphey-Reyes A. Quantitative research designs: Experimental, quasi-experimental, and descriptive. Jones Bartlett Learn 2017:155-83.

[10] Keefe G, Wharrad HJ. Using e-learning to enhance nursing students' pain management education. Nurse Educ Today 2012;32:e66-72. https://doi.org/10.1016/j.nedt.2012.03.018.

[11] Carter LM. Critical Thinking Dispositions in Online Nursing Education. J Distance Educ 2008;22:89-113.

[12] Spangle M. Approaching value-centered education through the eyes of an electronic generation: Strategies for distance learning. Annu Meet Natl Commun Assoc 2002.

[13] Morin KH. Nursing education after COVID-19: Same or different? J Clin Nurs 2020;29:3117-9. https://doi.org/10.1111/jocn.15322.

[14] Gerdprasert S, Pruksacheva T, Panijpan B, Ruenwongsa P. An interactive web-based learning unit to facilitate and improve intrapartum nursing care of nursing students. Nurse Educ Today 2011;31:531-5. https://doi.org/10.1016/j.nedt.2010.10.008.

[15] Durmaz A, Dicle A, Cakan E, Cakir Ş. Effect of screen-based computer simulation on knowledge and skill in nursing students' learning of preoperative and postoperative care management: A randomized controlled study. CIN - Comput Informatics Nurs 2012;30:196-203. https://doi.org/10.1097/NCN.0b013e3182419134.

[16] Gunawardena CN, Zittle FJ. Social presence as a predictor of satisfaction within a computer-mediated conferencing environment. Int J Phytoremediation 1997;21:8-26. https://doi.org/10.1080/08923649709526970.

[17] Mccutcheon K, Lohan M, Traynor M, Martin D. A systematic review evaluating the impact of online or blended learning vs. face-to-face learning of clinical skills in undergraduate nurse education. J Adv Nurs 2015;71:255-70. https://doi.org/10.1111/jan.12509.

[18] Syafrandinel R. Dampak Pemanfaatan Sistem E-learning pada Singapore General Hospital untuk Meningkatkan Kualitas SDM 2019.

[19] Kaveevivitchai C, Chuengkriankrai B, Luecha Y, Thanooruk R, Panijpan B, Ruenwongsa P. Enhancing nursing students' skills in vital signs assessment by using multimedia computer-assisted learning with integrated content of anatomy and physiology. Nurse Educ Today 2009;29:65-72. https://doi.org/10.1016/j.nedt.2008.06.010.

[20] Kusumawaty I, Yunike, Podojoyo. The Complexity of Caring for People with Mental Disorders: Family Challenges in Contributing to Horticultural Therapy. Pakistan J Med Heal Sci 2020;14:1442-6.

[21] Kusumawaty I. Pendampingan Terhadap Kelompok Orang Dalam Pemantauan Covid-19 Melaksanakan Hipnosis Lima Jari di Rumah Sehat Sumsel. CARADDE J Pengabdi Kpd ... 2020;3.

[22] Santoso B, Sahar J, Wiarsih W. Pengalaman Mantan Penggunadalam Penyalahgunaan Napza Suntik. J Keperawatan Indones 2012;15:117-22. https://doi.org/10.7454/jki.v15i2.36. 